\title{
HISTORIOGRAPHICAL LITERATURE IN THE NEW TESTAMENT PERIOD (1ST AND 2ND CENTURIES CE) ${ }^{1}$
}

\author{
Eve-MARIE BeCKer
}

The intention of the present essay is to present the themes and forms of historiographical literature in the New Testament period. I approach this as a literary-historical task, ${ }^{2}$ i.e. as a thematical and form-specifical contextualization of New Testament literature in the frame of ancient historiographical genres. So I shall describe the literary-historical framework in which the New Testament texts have their genesis, and against this background, I shall assess precisely this genesis of the New

${ }^{1}$ For fundamental bibliographical information with an overview of the literary history of Hellenistic historiography, cf. H. Lühken, "Synopse der griechischen Literatur," in Einleitung in die griechische Philologie, H.-G. Nesselrath (Stuttgart: Teubner, 1997); H. Lühken, "Synopse der römischen Literatur," in Einleitung in die lateinische Philologie, F. Graf (Stuttgart: Teubner, 1997); O. Lendle, Einführung in die griechische Geschichtsschreibung: Von Hekataios bis Zosimos (Darmstadt: Wissenschaftliche Buchgesellschaft, 1992); K. Meister, Die griechische Geschichtsschreibung: Von den Anfängen bis zum Ende des Hellenismus (Stuttgart: Kohlhammer, 1990); D. Flach, Römische Geschichtsschreibung, 3rd ed. (Darmstadt: Wissenschaftliche Buchgesellschaft, 1998); A. Mehl, Römische Geschichtsschreibung: Grundlagen und Entwicklungen. Eine Einführung (Stuttgart: Kohlhammer, 2001); C. R. Holladay, ed., Fragments from Hellenistic Jewish Authors, 1: Historians, SBL.TT (Chico: Scholars Press, 1983); M. Landfester, ed., Geschichte der antiken Texte: Ein Werklexikon, DNPS 2 (Stuttgart: Metzler, 2007); R. Nickel, Lexikon der antiken Literatur (Düsseldorf: Artemis \& Winkler, 1999); M. von Albrecht, Geschichte der römischen Literatur von Andronicus bis Boethius, 2 vols., 2nd ed. (München: Deutscher Taschenbuch Verlag, 1997); D. Gall, Die Literatur in der Zeit des Augustus (Darmstadt: Wissenschaftliche Buchgesellschaft, 2006); C. Reitz, Die Literatur im Zeitalter Neros (Darmstadt: Wissenschaftliche Buchgesellschaft, 2006); E.-M. Becker, Das Markus-Evangelium im Rahmen antiker Historiographie, WUNT 194 (Tübingen: Mohr Siebeck, 2006); C. Moreschini and E. Norelli, Early Christian Greek and Latin Literature: A Literary History, 1: From Paul to the Age of Constantine (Peabody: Hendrickson Publishers, 2005); W. Schneemelcher, ed., Neutestamentliche Apokryphen in deutscher Übersetzung, 1: Evangelien; 2: Apostolisches, Apokalypsen und Verwandtes (Tübingen: Mohr Siebeck, 1990; 6th ed. 1997); A. Feldherr, ed., The Cambridge Companion to the Roman Historians (Cambridge: Cambridge University Press, 2009); J. Frey et al., eds., Die Apostelgeschichte im Kontext antiker und frühchristlicher Historiographie, BZNW 162 (Berlin: de Gruyter, 2009).Concerning intercultural studies in the literary development of historiography cf. recently, K.-P. Adam, ed., Historiographie in der Antike, BZAW 373 (Berlin: de Gruyter, 2008).

${ }^{2}$ On literary-historical studies in the field of early Christian literature in recent years, cf. G. Theissen, Die Entstehung des Neuen Testaments als literaturgeschichtliches Problem, Schriften der Philosophisch-historischen Klasse der Heidelberger Akademie der Wissenschaften 40 (Heidelberg: Winter, 2007); Moreschini and Norelli, Literature. 
Testament texts and writings as a literary-historical phenomenon, ${ }^{3}$ i.e. as a process of a thematical and formal adaptation and transformation of certain types of ancient historiographical literary possibilities. The comparative criterion consists of stories which tell a story, i.e. historiographical texts in the narrower and broader senses of this term. ${ }^{4}$ The New Testament period is understood as the space of time in which those early Christian texts and writings came into being which were later collected in the canon of the so-called New Testament, i.e. the first century and the first third of the second century of the Common Era.

In the first section of this essay (1), I shall describe the literaryhistorical presuppositions of the composition of historiographical literature in this period. These are determined by the Hellenistic period, culture, and literature. ${ }^{5}$ In the second section (2), I present significant literary-historical developments and literary representatives of the historiographical literature in the so-called early Imperial period (ca. 30 BCE-ca. 120 CE) in the Greek-Hellenistic, Roman, and early Jewish spheres. In the third section (3), I shall discuss where early Christian texts, especially the gospel literature, belong in the framework of the literary history of Hellenistic historiography.

\section{Themes, Types, and Forms of Hellenistic Historiography}

\subsection{Basic Questions}

Historiographical literature in the Hellenistic age ${ }^{6}$ produces a variety of themes, types, and forms. On the one hand, these display culturally specific features in the Greek, Roman, and early Jewish spheres, e.g. the literary elaboration of the period of Alexander and his successor

${ }^{3}$ K. Backhaus and G. Häfner, Historiographie und fiktionales Erzählen: Zur Konstruktivität in Geschichtstheorie und Exegese, BThSt 86 (Neukirchen-Vluyn: Neukirchener Verlag, 2007), choose a philological rather than a literary-historical approach.

${ }^{4}$ On the definition of historiographical texts, see below.

${ }^{5}$ For an introduction to the history of research into historiography, cf. Flach, Geschichtsschreibung, 1-3.

${ }^{6}$ The definition of "Hellenism" which is relevant to cultural and literary history follows the classic definitions in the study of the classical period since J. G. Droysen. Cf. e.g. D. Timpe, "Hellenismus I.," RGG 4th ed., 3 (2000): 1609-1610. Cf. most recently also B. Meißner, Hellenismus (Darmstadt: Wissenschaftliche Buchgesellschaft, 2007). 
kings in Greek historiography, ${ }^{7}$ the culture of remembrance of the early Roman historians, influenced by annals (e.g. Q. Fabius Pictor), ${ }^{8}$ and the narrative-legendary elaboration of biblical-historical narrative material in Jewish Hellenistic historiography (e.g. Eupolemus, Artapanus). ${ }^{9}$ On the other hand, there is a linguistic and literary cultural transfer and cultural exchange precisely in Hellenism, and this can be seen both in the shaping of individual themes and forms and in the creation of mixed forms. The definition of the so-called Hellenistic age usually envisages a space of time which is defined by political events (ca. 330-30 BCE). ${ }^{10}$ The following presentation aims to describe the cultural, intellectual, and literary panorama in which the Greek, Roman, and Early Jewish historiographers were working until the beginning of the Imperial period (from ca. $30 \mathrm{BCE}$ ).

The early Hellenistic period is marked by the hegemony of the Hellenes in the eastern Mediterranean region and neighboring lands in the aftermath of Alexander the Great, and by a considerable growth in literary production in the Greek language. At the end of the fourth and beginning of the third centuries, a social-historical transformation occurs in Greek historiography, which is also significant for the history of culture and literature: it is now that the figure of the so-called court historian emerges. ${ }^{11}$ This transformation is the beginning of a close link between politics and historiography. Historiography had always been employed as a political instrument; but this new link now also generated a number of literary forms and genres.

Cf. e.g. Lendle, Einführung, 180-181.

${ }^{8}$ Cf. Mehl, Geschichtsschreibung, 42-44.

${ }^{9}$ Cf. Holladay, Fragments.

${ }^{10}$ On this, cf. J. Bleicken, Verfassungs- und Sozialgeschichte des Römischen Kaiserreiches, 2 vols., UTB 838/839 (Paderborn: Schöningh, 4th ed., 1995 in 3rd ed., 1994), who dates the beginning of the Roman Imperial period to $31 / 27$ BCE (1:9).

11 "In the city state of the classical epoch of Greece, the historians were prosperous citizens, members of the leading classes of the Greek poleis. At the end of the classical epoch, when monarchies came into existence in the Greek world-and with the monarchies, courts-and with the courts" a new ruling society, "the figure of the historian who lived at court and was at the service of a ruler also came into existence": B. Meißner, Historiker zwischen Polis und Königshof: Studien zur Stellung der Geschichtsschreiber in der griechischen Gesellschaft in spätklassischer und frühhellenistischer Zeit, Hyp. 99 (Göttingen: Vandenhoeck \& Ruprecht, 1992), 4-5. 
The themes of Hellenistic historiography in its Greek and later Roman forms lie initially in the field of Persian, Macedonian, and Greek history; subsequently, they concentrate on the protagonists of this history, i.e. Alexander the Great and his successor kings. This means that Hellenistic historiography increasingly takes on biographical or person-centered traits, which we also find in Jewish Hellenistic historiography (e.g. the Moses fragment in Artapanus). ${ }^{12}$ At the same time, a large number of historiographical methods and presentations developed in Hellenism; of these, only "tiny splinters have come down to us." 13 Accordingly, every presentation of the literary history of the classical age is conditioned in advance by presuppositions which belong to textual history, i.e. by the transmission of the texts and writings available to us. ${ }^{14}$

\subsection{Demarcations: Antiquarian Forms, or Literature and Historiography Orientated to Tradition ${ }^{15}$}

We must draw a distinction between the so-called antiquarian literature of the classical period and historiography in the broader and narrower senses. The term antiquarian literature has been applied since the Renaissance (with an allusion to Varro's "Antiquities") to all those historical forms which do not correspond "to the HerodoteanThucydidean concept of the historiography which is based on the study of politics and war." ${ }^{16}$ It is in this way that antiquarian historical literature has been distinguished from historiography, at least from the beginning of the modern period onwards. This demarcation vis-à-vis antiquarian literature shows us one essential characteristic of historiographical literature: the latter is not limited to the mere collection of

12 Cf. Holladay, Fragments, 208-210.

13 Lendle, Einführung, 205. The following differentiations follow above all H.-G. Nesselrath, "Geschichte der griechischen Literatur. Die Kaiserzeit," in idem, Einleitung in die griechische Philologie (Stuttgart: Teubner, 1997), 269-293, at 279-281.

14 On the criteria on which the collection of the fragments of Greek historians by F. Jacoby (FGrHist) is based, cf. idem, "Ueber die Entwicklung der griechischen Historiographie und den Plan einer neuen Sammlung der griechischen Historikerfragmente," Klio 9 (1909): 80-123.

15 On this concept, cf. K. Sallmann, ed., Die Literatur des Umbruchs: Von der römischen zur christlichen Literatur 117 bis 284 n.Chr., Handbuch der Lateinischen Literatur der Antike 4 (München: C. H. Beck, 1997).

16 A. Momigliano, Die Geschichtsschreibung: Griechische Literatur, ed. E. Vogt, NHL 2 (Wiesbaden: Akad. Verl.-Ges. Athenaion, 1981), 305-336, at 310. 
historical information, but aims to present this in such a way that it is both systematized and interpreted. This applies already to the beginnings of Greek and Roman historiography, and to the Christian history of the church. Greek historiography is essentially a child of epic forms (myths) and of geographical forms (descriptions of the earth and travel narratives); ${ }^{17}$ Roman historiography has its precursors in the annales maximi and the so-called fast $i i^{18}$ and ecclesiastical historiography has its starting point in the chronographical form of the lists of bishops. ${ }^{19}$ This means that history by definition involves the systematization and interpretation of historical events and information.

\subsection{The Definition of "Historiography" in the Broader and Narrower Senses}

Against this background, how can we define the genre of historiographical literature? Let us first mention two traits which are significant for the definition of the theme or contents and the literary form of historiography. Thematically speaking, historiography is engaged in the narrative of historically relevant facts and events. From a literaryformal aspect, historiographical literature employs the form of prose from Herodotus onwards. ${ }^{20}$ The presentation of history in the form of lists, myths, epics, or poetry can at best be called precursor forms of historiography; these do not genuinely belong to the macro-genre of "historiography."

${ }_{17}$ In general, cf. Meister, Geschichtsschreibung. Cf. also B. Meissner, "Anfänge und frühe Entwicklungen der griechischen Historiographie," in Die antike Historiographie und die Anfänge der christlichen Geschichtsschreibung, ed. E.-M. Becker, BZNW 129 (Berlin: de Gruyter, 2005), 83-109.

${ }^{18}$ Cf. Mehl, Geschichtsschreibung. For a critical evaluation of the annales maximi, however, cf. H. Beck and U. Walter, "Die frühen Römischen Historiker 1: Selbstbewusstsein-Traditionsbildung-Experiment," in Die frühen Römischen Historiker 1: Von Fabius Pictor bis Cn. Gellius, trans. with commentary by H. Beck and U. Walter, TzF 76 (Darmstadt: Wissenschaftliche Buchgesellschaft, 2001), 17-53. Cf. J. Rüpke, "Fasti. Quellen oder Produkte römischer Geschichtsschreibung?," Klio 77 (1995): 184-202.

${ }^{19}$ Cf. W. Wischmeyer, "Wahrnehmungen von Geschichte in der christlichen Literatur zwischen Lukas und Eusebius. Die chronographische Form der Bischofslisten," in Die antike Historiographie und die Anfänge der christlichen Geschichtsschreibung, ed. Becker, 263-276.

${ }^{20}$ Cf. W. Schadewaldt, Die Anfänge der Geschichtsschreibung bei den Griechen: Herodot-Thukydides, 4th ed. stw 389 (Frankfurt: Suhrkamp, 1995), 19-21. 
A second differentiation is necessary at this point. The macro-genre of historiography-i.e. historiography in the broader sense-encompasses a variety of individual forms and genres, including historiography in the narrower sense. How can we define historiography in the broader sense and historiography in the narrower sense? Where does the line of demarcation run? One possible differentiating definition affirms that historiography in the broader sense includes those prose texts which are concerned in various individual genres and forms with the presentation of historical themes and events (e.g. as biography, autobiography, monograph, ethnography), while historiography in the narrower sense (following Hubert Cancik) designates an "especially highly developed form of historiography" 21 which must be distinguished specifically from biographical and autobiographical forms, etc. ${ }^{22}$

\subsection{Defining the Distinctions between Historiography, Biography, and Autobiography}

We shall now look in greater detail at the differentiation between historiography in the narrower sense and biography. ${ }^{23}$ We must first of all locate the phenomenon of biographical literature in the context of history in general, and specifically of cultural history, since the growing importance of biographical literature has historical and political reasons: "With the decline of the city states and the rise of the monarchies...the reign of a ruler became the natural unit of time of political history: historiography became increasingly biographical." ${ }^{24}$ It is thus scarcely possible to use the self-understanding of the authors as a criterion for distinguishing between historiographical and biographical literature. For example, those who told the story of Alexander certainly understood themselves as historians, since the object of their work was the personality and the activity of Alexander as a theme

${ }^{21}$ H. Cancik, "Geschichtsschreibung," NBL 1 (1991): 813-882, at 813-814.

22 Cf. also Becker, Markus-Evangelium, 62-63.

${ }^{23}$ On this, cf. those definitions which are seldom the object of further reflection, e.g. in D. Dormeyer, review of E.-M. Becker, Das Markus-Evangelium im Rahmen antiker Historiographie, BZ 52 (2008): 132-135.

${ }^{24}$ Momigliano, Geschichtsschreibung, 317. 
belonging to the history of events and to history in general (e.g. Cleitarchus of Alexandria, FGrHist 137). ${ }^{25}$

At the same time, however, steps were taken already in antiquity to distinguish between historiography and biography. ${ }^{26}$ For example,

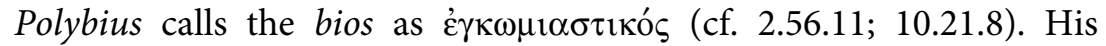

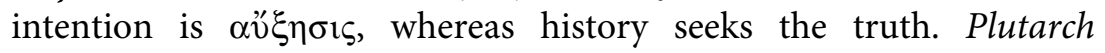
(Alex. 1, and frequently) explicitly wishes to write "history" in the form of Bíos, since his intention is to portray the character of the

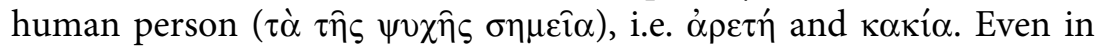
the so-called apodictic historiography, which makes use of the biographical excursus, the distinction between historiography and biography is preserved. ${ }^{27}$ In Roman literature too, the distinction between historiographical writings in the narrower sense and biographical writings (which included the literature of the exitus illustrium virorum) was maintained at least until the third or fourth century (cf. e.g. Pliny, Ep. 8.12.4; 5.5.3). ${ }^{28}$

Finally, autobiographical forms (hupomnêmata and commentarii) are related to biographical literature. ${ }^{29}$ Aratus of Sicyon (ca. 271-213 $\mathrm{BCE}$ ) is known as one of the earliest authors of hupomnemata in the

${ }^{25}$ Cf. Lendle, Einführung, 168-170.

${ }^{26}$ Cf. A. Dihle, Die Entstehung der historischen Biographie, SHAWPH 1986.3 (Heidelberg: Carl Winter, 1987); A. Momigliano, The Development of Greek Biography (Cambridge: Harvard University Press, 1971).

27 "The apodictic historiography employed the biographical excursus to make historical causality clear, but it distinguished historiography from biography": F. Winkelmann, "Historiographie," RAC 15 (1991): 724-765, at 730. New Testament exegetes often fail to reflect consistently on the differentiation between historiography and biography and to offer an evaluation of this. Cf. e.g. D. Dormeyer, Plutarchs Cäsar und die erste Evangeliumsbiographie des Markus: Rom und das himmlische Jerusalem. Die frühen Christen zwischen Anpassung und Ablehnung, ed. R. von Haehling (Darmstadt: Wissenschaftliche Buchgesellschaft, 2000), 29-52; idem, Das Markusevangelium als Idealbiographie von Jesus Christus, dem Nazarener, 3rd ed. SBB 43 (Stuttgart: Verlag Katholisches Bibelwerk, 2002).

28 "It is only the imperial biography-with Suetonius as its ancestor-that... is made a vehicle of historiography in the third century CE.... But until the fourth century, its status as an historiographical form was disputed"; Winkelmann, "Historiographie," 738 .

${ }_{29}$ For an overview, cf. K. Meister, "Autobiographische Literatur und Memoiren (Hypomnemata)," in Purposes of History: Studies in Greek Historiography from the 4th to the 2nd Centuries B.C., ed. H. Verdin et al., StHell 30 (Leiden: Brill 1990), 83-89. Cf. also in general H. Sonnabend, Geschichte der antiken Biographie: Von Isokrates bis zur Historia Augusta (Stuttgart and Weimar: Verlag J. B. Metzler, 2002). 
Hellenistic period (cf. FGrHist 231). ${ }^{30}$ Autobiographical forms received a tremendous impetus in the sphere of Roman literature above all in the transition from the Roman Republic to the principate, thanks to the prominent works by Julius Caesar (Commentarii) ${ }^{31}$ and Augustus (res gestae/Monumentum Ancyranum). ${ }^{32}$ From the Hellenistic period onwards, experts in rhetoric "studied the form of the older historiography.... in order to determine the canon and to distinguish... between history, biography, and antiquarian studies." ${ }^{33}$

\subsection{Types and Modes of Hellenistic Historiography}

Hellenistic historiography displays a variety of literary types and modes which allow us to see something of the intellectual world and the rhetorical-literary schooling of the historiographers. We shall therefore give a brief description of some of these, e.g. the rhetorical-rhetoricizing, the mimetic, the apodictic, and the pragmatic historiography.

In the rhetorical historiography, the historical discourse takes the form of narration and argumentation, and the tradition possesses authority. The aim of historiography is to facilitate correct evaluations and decisions in the contemporary conflicts. In the first century BCE, Roman historiography is influenced by the Hellenistic-Peripatetic rhetorical historiography in the way in which it copes with the contemporary political crises. An important factor in the increase in the rhetorical tendencies of Roman historiography was the rhetoricization of historical narration which was demanded especially by Cicero (Orat. $2.54-56) .^{34}$

${ }^{30}$ To a large extent, his writings can be regarded as unfalsified and devoid of literary artifice, although they have a subjective coloring. Cf. Lendle, Einführung, 192194.

${ }^{31}$ Cf. Mehl, Geschichtsschreibung, 68-70.

${ }^{32}$ Cf. F. Blumenthal, "Die Autobiographie des Augustus," Wiener Studien 35 (1913): 113-130 and 267-288, 36 (1914): 84-103. Most recently, cf. also K. Bringmann, ed., Augustus: Schriften, Reden und Aussprüche, WdF 91 (Darmstadt: Wissenschaftliche 2008 Buchgesellschaft.

33 D. Harth, "Geschichtsschreibung," Historisches Wörterbuch der Rhetorik 3 (1996): $832-870$, at 837 .

${ }^{34}$ The narrative form has a forensic component, since it takes place in an inductive form. This link is already found in Aristotle: cf. Rhet. 2.1393a20. On Isocrates and Cicero, cf. also A. Demandt, Geschichte als Argument: Drei Formen politischen Zukunftsdenkens im Altertum (Konstanz: Universitätsverlag, 1972), 18-20 and 30-32. Cf. in general Harth, "Geschichtsschreibung", 839-840. 
In his debate with the so-called mimetic historiography of a Duris of Samos (born $330 \mathrm{BCE})^{35}$ and the related pathetic historiography (e.g. Phylarchus), ${ }^{36}$ as well as with the apodictic historiography of a Hieronymus of Cardia (third/second century), ${ }^{37}$ Polybius propagates a presentation which concentrates on the relevant historical questions. He attacks rhetorical and dramatizing elements in historiography, and coins the concept of pragmatic historiography. Its methodological approach (the examination of written sources, "autopsy," political action: cf. 12.25e1) is already found in Herodotus and Thucydides. ${ }^{38}$ Unlike tragedy, history is interested in "truth and usefulness to the reader." ${ }^{39}$ Through this apodictic interest, Polybius establishes a demarcation line vis-à-vis the pathetic historiography of Phylarchus (cf. 2.56.11-12). Historiography has practical and moral goals (1.1.2): ${ }^{40}$ Polybius sees its purpose as "contributing to the ability to act" in the political and military spheres $(3.59 .3-5 ; 12.8 .1 ; 16.14 .3-10$; etc. $) .^{41}$ In general, therefore, we find a basic moralizing and pragmatizing trait in the various types of Hellenistic historiography.

${ }^{35}$ We find reflections on the Hellenistic historiography at the beginning of the Makedonika (FGrHist 76 F1). Cf. also Aristotle, Poet. 14.1453b11/12, and Lendle, Einführung, 186-187. Duris of Samos "applied" the Aristotelian principles of the mimetic composition of fables "to history, in order to intensify the character of the narrative as an aesthetically effective and moral-didactic appeal": Harth, "Geschichtsschreibung," 836.

${ }^{36}$ Cf. also Winkelmann, "Historiographie," 729, and Lendle, Einführung, 202. On pathos and emotionality in historiography in general, cf. most recently J. Marincola, "Beyond Pity and Fear: The Emotions of History," Ancient Society 33 (2003): 285315.

${ }^{37}$ FGrHist 154.

${ }^{38}$ Cf. Winkelmann, "Historiographie," 729. Polybius's manner of writing follows the rhetorical pattern narratio-probatio-applicatio (cf. Harth, "Geschichtsschreibung," 836). On the historical method of Thucydides, cf. also most recently H. Sonnabend, Thukydides, Studienbücher Antike 13 (Hildesheim: Olms, 2004), esp. 55-57.

${ }^{39}$ Winkelmann, "Historiographie," 729.

${ }^{40}$ Cf. H. Tränkle, Livius und Polybios (Basel and Stuttgart: Schwabe, 1977); A. M. Eckstein, Moral Vision in The Histories of Polybius (Berkeley: University of California Press, 1995), esp. 272-274.

${ }^{41}$ Meißner, Historiker, 557. 


\subsection{Reflections in Classical Antiquity on the Theory and Method of Historiography}

Scattered "methodological observations" are found in the works of the ancient historians, ${ }^{42}$ especially when they discuss the exordium.$^{43}$ For example, Livy speaks critically of the relationship between historiography and poetry. ${ }^{44} \mathrm{~A}$ number of theoretical discussions of the essence, significance, and function of historiography had a decisive influence on the form of historiographical works. In his conception of literary composition, Aristotle defines history as a chance narrative of events (Poet. 9.1451b). Since poetry communicates what could happen accord-

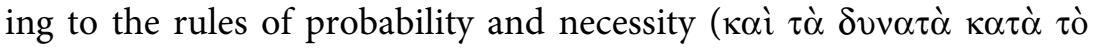

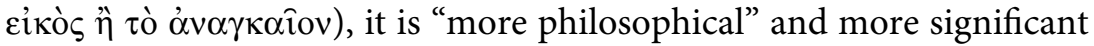

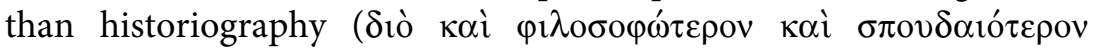

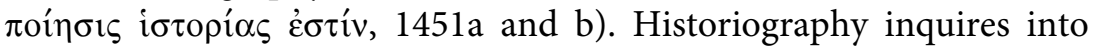
what is specific, whereas poetry inquires into what is general

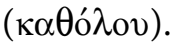

Cicero's discussion reflects the historiographical theories of the late Roman Republic. He understands history as magistra vitae, vita memoriae, and lux veritatis (Orat. 2.36), and as munus oratoris maximum (Orat. 2.62). ${ }^{45}$ Contrary to the Roman tradition of the annales maximi, which was meant only to preserve the memory of places, times, human persons, and deeds, Cicero favors a rhetorically shaped form of historiography which is comparable to the Greek tradition (Orat. 2.51-53; Leg. 1.6-8). In the Flavian period, which brings a "classicistic reaction," ${ }^{46}$ Quintilian gives us glimpses of the historiographical theories of the Imperial period (Orat. Inst. 10.1.31). ${ }^{47} \mathrm{He}$ posits a close relation-

\footnotetext{
${ }^{42}$ Winkelmann, "Historiographie," 732.

${ }^{43}$ Flach, Geschichtsschreibung, 9-11, refers to the following reflections on the theory of history in classical antiquity: Thucydides, 1.22.2-3; Cassius Dio, 53.19.4-5; Tacitus, Ann. 1.1.2f.; Hist. 1.1.2; Polybius, e.g. 12.25-27; 2.56.7-9.

${ }^{44}$ Cf. Livy, Praef. 1.13. Cf. also T. P. Wiseman, "History, Poetry, and Annales," in Clio \& the Poets: Augustan Poetry \& the Traditions of Ancient Historiography, ed. D. S. Levine and D. P. Nelis, MnS 224 (Leiden: Brill, 2002), 331-362, at 331-333.

${ }^{45}$ K.-E. Petzold, "Cicero und Historie," in idem, Geschichtsdenken und Geschichtsschreibung: Kleine Schriften zur griechischen und römischen Geschichte, Historia 126 (Stuttgart: F. Steiner, 1999), 86-109; M. Fleck, Cicero als Historiker, Beiträge zur Altertumskunde 39 (Stuttgart: Teubner, 1993), esp. 15-17.

${ }^{46}$ von Albrecht, Geschichte, 717.

${ }^{47}$ Cf. in general also A. D. Leeman, "Die römische Geschichtsschreibung," in Römische Literatur, ed. M. Fuhrmann, NHL 3 (Frankfurt: Akademische Verlagsgesellschaft Athenaion, 1974), 115-146, at 134-135.
} 
ship between historiography and poetry: historiography does not prove, but narrates in a literary form not bound by the rules of metre (...quodam modo carmen solutum est et scribitur ad narrandum, non ad probandum). "This makes it clear that Quintilian wishes to see an even stronger link between historiography and poetry than did Cicero." ${ }^{38}$ Quintilian is not the only one who takes this approach; he reflects the increased blurring of the distinction between historiography and poetry that we find in the Roman literature of the early Imperial period. ${ }^{49}$ Tacitus emphasizes the moral and ethical character of historiography. He sets out his understanding of the praecipuum munus annalium of history at Ann. 3.65: "The passage... states first what history's role should be in respect to good behaviour... and second what the purpose is in recording instances of bad behaviour." 50

Reflection on history in the sense of the elaboration of a technical ars historica is found only in Lucian, ${ }^{51}$ who composed the only "systematic monograph on historiography" 52 that has survived from the classical period. He addresses his methodological, linguistic, and substantial demands to the historian-demands that are directed against the customary historiography of contemporary imperial military campaigns, which were nothing other than exaggerated panegyrics. Lucian defines the distinction between poetry and history by saying that a poet is driven by a deity and by the Muses, and is therefore permitted to relate incredible things (H.c. 8). The following aspects must also be borne in mind when one writes historical works: the historian is writing for the instruction of posterity (H.c. 40f.), and this means that the purpose of history is to be of service by presenting the truth (H.c. 8). The historian's task is to present factual matters (H.c. 38-39). A good historian needs political acumen and skill in presentation (H.c. 34). The facts must be well chosen and critically evaluated; they should be based primarily on things one has personally witnessed, or on the

\footnotetext{
${ }^{48}$ Leeman, "Geschichtsschreibung," 135.

${ }^{49}$ On this, cf. most recently Wiseman, "History," esp. 353-354.

${ }^{50}$ T. J. Luce, “Tacitus on 'History's Highest Function': Praecipuum munus annalium (Ann. 3.65)," ANRW II 33.4 (1991): 2904-2927, at 2906-2907, emphasizing the difference from Livy, who offers instruction by means of examples. In Tacitus, we find the idea "that history can act as a deterrent" (2914).

${ }^{51}$ Cf. E. Keßler, “Ars historica," Historisches Wörterbuch der Rhetorik 1 (1992): 1046-1048, at 1046. Cf. in general G. Avenarius, Lukians Schrift zur Geschichtsschreibung (Meisenheim: Hain, 1956).

52 Winkelmann, "Historiographie," 732.
} 
testimony of credible witnesses (H.c. 47). The historian must begin by drawing up an outline of his presentation, which he then fills in with details (H.c. 48). The style should be generally comprehensible and simple (H.c. 43-45). The course of the narrative should be related briefly and precisely (H.c. 50, 56-57). An historical work needs no preface; a short summary of its contents is sufficient (H.c. 52). In these reflections, Lucian gives an interesting insight into the ancient theory about the production and reception of historiography and into the evaluation of the literary genre of "history" in classical antiquity.

\subsection{Themes and Forms of Early Jewish Historiography}

Jewish Hellenistic historiography ${ }^{53}$ aims both at assimilation and at the preservation of the identity of the historiographical themes and forms of an Old Testament and Jewish character in the context of the mixed Hellenistic cultures. Early Jewish historiography thus lives in the tension between assimilation and the preservation of identity. ${ }^{54}$ The diaspora Jews, who had largely lost their knowledge of Hebrew and Aramaic, established a historiography in Greek. Jewish Hellenistic historiography displays not only linguistic, but also formal influence on the part of Greek historiography. For example, 1 Maccabees contains some elements, such as the ethnographical chapter about Rome, which are related to Greek historiography. This book is based on various written sources, including letters and documents which the author may have consulted in an archive in Jerusalem. His presentation also relies on legendary and oral traditions ${ }^{55} 2$ Maccabees "resembles much more strongly the popular Greek historiography with its pronounced love of miracles and remarkable events." ${ }^{26} 2$ Maccabees, "as a work of

${ }^{53}$ Cf. also the introduction in E. Schürer, The History of the Jewish People in the Age of Jesus Christ (175 B.C.-A.D. 135). A New English Version, revised and ed. G. Vermes and F. Millar 1 (Edinburgh: Clark, 1973), 19-122.

${ }^{54}$ On this, cf. the overview by $\mathrm{O}$. Wischmeyer, "Orte der Geschichte und der Geschichtsschreibung in der frühjüdischen Literatur," in Die antike Historiographie und die Anfänge der christlichen Geschichtsschreibung, ed. Becker, 157-179. Cf. also G. E. Sterling, Historiography and Self-Definition: Josephos, Luke-Acts and Apologetic Historiography, NovTSup 64 (Leiden: Brill, 1992).

${ }_{55}$ Cf. e.g. K.-D. Schunck, 1. Makkabäerbuch, JSHRZ I/4 (Gütersloh: Gütersloher Verlagshaus, 1980), 291.

56 Momigliano, Geschichtsschreibung, 326. "The fragments of Greco-Jewish histories from the first two centuries of the Hellenistic period offer a tantalizing glimpse into the process of assimilation and cultural polemics which were at work among Jews 
the pathetic and rhetorical historiography which aimed at great dramatic effects and was dominant in Hellenism," conforms completely to "contemporary Greek historiography. Indeed, 2 Maccabees is the only work of this genre which has survived in its entirety." ${ }^{57}$ The historiographer Flavius Josephus, writing in the early Imperial period, follows even more directly the forms and elements of Greek historiography.

Despite linguistic and cultural processes of adaptation, i.e. the use of the Greek language and the consequences this had for early Jewish literature and historiography, ${ }^{58}$ the literary products of Jewish Hellenistic historiography nevertheless largely preserve their own specific character. Religious aspects play a central role here, ${ }^{59}$ as does the fact that there was little interest in individual historical themes and in history in general in Israel, and especially in Diaspora Judaism, in the second century BCE, with the exception of the Maccabean conflicts. ${ }^{60}$ Instead of writing a continuous history of contemporary events, biblical traditions are elaborated into contemporary narratives ${ }^{61}$ (cf.

during the period, but they make little or no contribution to the understanding of contemporary political developments. Such is the concern of the two major Jewish histories of the period, 1 and 2 Maccabees": H. W. Attridge, "Historiography," in Jewish Writings of the Second Temple Period, ed. M. E. Stone, CRINT 2 (Assen: Van Gorcum, 1984), 157-184, at 171. On the significance of the Books of Maccabees for early Jewish historiography, cf. most recently also H. Lichtenberger, "Geschichtsschreibung und Geschichtserzählung im 1. und 2. Makkabäerbuch," in Die antike Historiographie und die Anfänge der christlichen Geschichtsschreibung, ed. Becker, 197-212.

${ }^{57}$ C. Habicht, 2. Makkabäerbuch, JSHRZ I.3 (Gütersloh: Gütersloher Verlagshaus 1976), 189.

58 "All the nations that came into contact with the Greeks in the Hellenistic age...produced books in Greek about their national history": A. Momigliano, The Classical Foundations of Modern Historiography (Berkeley: University of California Press, 1990), 24.

${ }^{59}$ Cf. also M. Pohlenz and P. Wendland, "Die griechische Prosa," in Einleitung in die Altertumswissenschaft 1, Part 3, ed. A. Gercke and E. Norden, 3rd ed. (Leipzig: B. G. Teubner, 1927), 64-166, at 161-162.

${ }_{60}$ "On the one hand the postbiblical Jews really thought they had in the Bible all the history that mattered: superevaluation of a certain type of history implied undervaluation of all other events. On the other hand the whole development of Judaism led to something unhistorical, eternal, the Law, the Torah. The significance which the Jews came to attach to the Torah killed their interest in general historiography": Momigliano, Foundations, 23. On the historical sources for early Jewish history, cf. Schürer, History, 19-43.

${ }^{61}$ Cf. also R. Doran, “The Jewish Hellenistic Historians Before Josephus," ANRW II, 20.1 (1987): 246-297, at 295. 
Artapanus).$^{62}$ This is why it is difficult to define the specific genre of the early Jewish historiographical writings and thus to demarcate them vis-à-vis the rest of early Jewish literature. ${ }^{63}$ Historical themes are given an arbitrary literary form in other areas of early Jewish literature which are not counted among the "historical writings" in the broader sense (prophecy, apocalyptic, sapiential literature). These historical themes can be understood only against the background of the propheticapocalyptic coding (e.g. Dan 12) or of sapiential instruction (Sirach), ${ }^{64}$ and are thus accessible only to specific groups.

Among the surviving Jewish Hellenistic historical works, we must distinguish between (a) those that have survived intact (1 Esdras, 1-3 Maccabees) and were included in the Septuagint and in the Vulgate canon, and $(b)$ the mostly brief fragments of historical works which survive only in compilations by later writers. Eusebius (especially in Praeparatio evangelica 9), Clement of Alexandria, and Josephus were not the first to transmit fragments of the Jewish Hellenistic historiographers; this had been done earlier by the Hellenistic historiographer L. Cornelius Alexander Polyhistor (born $105 \mathrm{BCE}$ ) in his work On the Jews. ${ }^{65}$ The fragments refer to writers who are orthonymous, but about whom scarcely any historical information survives; references to anonymous authors (Ps.-Eupolemus) or pseudepigraphical writers (Ps.-Hecataeus) are less frequent. Nevertheless, there is a tendency in

${ }^{62}$ On this, cf. Becker, Markus-Evangelium, 178-180: eadem, “Artapanos: 'Judaica'. A Contribution to early Jewish Historiography," in History and Identity: How Israel's Later Authors Viewed Its Earlier History, ed. N. Calduch-Benages et al. DCLY 2005 (New York: de Gruyter, 2006), 297-320. Concerning a poetic author like Ezekiel the Tragedian who in his Exagoge also uses the Exodus-traditions cf. C. R. Holladay, ed., Fragments from Hellenistic Jewish Authors 2: Poets, SBLTT (Atlanta: Scholars Press, 1989), 301-529. Cf. latest also: P. Lanfranchi, L'Exagoge d'Ezéchiel le Tragique: Introduction, texte, traduction et commentaire, Studia in Veteris Testamenti pseudepigrapha 21 (Leiden: Brill, 2006).

${ }^{63}$ Cf. U. Mittmann-Richert, Einführung zu den historischen und legendarischen Erzählungen, JSHRZ VI.1 (Gütersloh: Gütersloher Verlagshaus, 2000), 1: “The only works that can be called historical writings in the narrower sense of the term are 1 and 2 Maccabees..."

${ }^{64} \mathrm{Cf}$. the reflections on the historiographical character of some Qumran texts (e.g. the Damascus Document) and Sirach by B. Z. Wacholder, "Historiography of Qumran: The Sons of Zadok and Their Enemies," in Qumran between the Old and New Testament, ed. F. H. Cryer and T. L. Thompson, JSOTSup 280 (Sheffield: Sheffield Academic Press, 1998), 347-377.

65 The fundamental study of this work is J. Freudenthal, Alexander Polyhistor und die von ihm erhaltenen Reste judäischer und samaritanischer Geschichtswerke, Hellenistische Studien, vol. 1 and 2 (Breslau: H. Skutsch, 1875), esp. 16-18. 
Jewish literature for authors to remain anonymous. We find the phenomenon of orthonymous authorship first in Sirach, and Martin Hengel has emphasized that this is connected with the "discovery of the individuality of the author" in the "Hellenistic period." 66 (c) Josephus represents an independent type of historiographical literature, which must be evaluated in the context of Hellenistic Roman historiography.

\section{Tendencies and Representatives of the Historiography of the Early Imperial Period}

\subsection{Basic Questions}

As we have seen, Greek historiography in the Hellenistic Roman period displays a large number of historiographical conceptions and "an immense volume of production." This makes it difficult to achieve an overview. ${ }^{67}$ In terms of literary history, this leads to a mingling of the historiographical genres. A strict classification of the various types of historiography according to genre-specific elements is virtually impossible. At most, historiography in the Hellenistic-Roman period can be classified according to "trends" and "themes." ${ }^{68}$ In the second century $B C E$, a political upheaval replaced the hegemony of the Hellenes by the hegemony of the Romans; modern European scholars who thought in classicistic terms once wrote that "The standstill and decline of the productive intellectual powers of the Greek East meant that in this period, Rome overtook the leading role and set the tone in the field of literature too." ${ }^{99}$

Roman historiography became more important than Greek historiography from the first century BCE onwards. In the Augustan period, the literature related to the Imperium Romanum-especially poetry, but also historiography-was produced in an affirmative or critical

${ }^{66}$ M. Hengel, Die Evangelienüberschriften, SHWPH 1984.3 (Heidelberg: C. Winter, 1984), 25.

${ }^{67}$ K. Meister, "Geschichtsschreibung II. Griechenland," DNP 4 (1998): 992-996, at 993; idem, Geschichtsschreibung, 80: "There is an immense volume of production, a great diversity of themes, and considerable differences in the manner of presentation."

${ }^{68}$ Cf. Meister, Geschichtsschreibung, 994.

${ }^{69}$ Pohlenz and Wendland, "Prosa," 109. 
proximity to the princeps (cf., e.g. Livy and Nicholas of Damascus) $;{ }^{70}$ Augustus promoted it and exercised an ideological influence on it. ${ }^{71}$ The autobiographical activity of Augustus himself (the Res Gestae), which was imitated by the subsequent principes, ${ }^{72}$ shows clearly that historiographical works were understood to have a programmatic function as mediators of the Augustan ideology, and that they were in fact employed in this way (cf. once again Nicholas). This tie was then loosened temporarily under the Julio-Claudian principes, ${ }^{73}$ but it took on renewed intensity under the Flavians (69-96 CE), with a conscious reference back to the Augustan age (cf. Quintilian). It is against this background that the historiographical works of Flavius Josephus and Tacitus must be understood. This also explains the increasing significance of biographical literature (cf. Suetonius and C. Nepos), which generated the genre of imperial biographies (Historia Augusta).

A factor of social history also left its mark on the literature of the early Imperial period. At the beginning of this period, the cultural influence of the "Italic dynasties" declined. The "provincialization" of Latin literature meant that literary traditions were "often preserved in a purer form in peripheral regions than in the center, which was very much exposed to innovations." ${ }^{\prime 74}$ The literary tendencies of the historiography of the early Imperial period are mentioned by the Roman historians themselves in the transition from the republic to the principate. A high didactic and moral function is attributed to historiography (cf. Livy, Praef. 10), so that history is not only "the remembering of past deeds and charismatic...values which renders these present, but also a 'lamp of truth"' (cf. Cicero, above). ${ }^{75}$ Awareness

70 "The Augustan regime, it seems, did not attempt to dominate historical writing as it did poetry": G. B. Conte, Latin Literature: A History (Baltimore: Johns Hopkins University Press, 1994), 369.

71 Cf. Conte, Literature, 251-253. On Augustan literature in general, cf. most recently the essays in Levine and Nelis, Clio of The Poets.

${ }^{72}$ On the commentarii literature of the early Imperial period, cf. J. Wilkes, "JulioClaudian Historians," CW 65 (1972): 177-203, at 181-183; R. G. Lewis, "Imperial Autobiography: Augustus to Hadrian," ANRW II.34.1 (1993): 629-706. On the Hypomnemata/Commentarii of Vespasian and Titus, cf. HRR 2.108 and the references by Josephus, Apion 1.56; Life 342, 358; cf. also Schürer, History, 32-33. On the Hypomnemata of Herod the Great, cf. Josephus, Ant. 15.174, and Schürer, History, 26-27.

73 Cf. in general Wilkes, "Historians."

${ }_{74}$ Quotation from von Albrecht, Geschichte, 709.

75 Harth, "Geschichtsschreibung," 839. 
of the auctoritas of the traditions permitted the historians to achieve the literary and stylistic synthesis of various forms of presentation. ${ }^{76}$

Thematically, the historiographical literature of the early Imperial period is concerned with Roman history; in literary-historical terms, it belongs to the tradition of Hellenistic historiography. ${ }^{77}$ A good example of this position in the history of culture and of literature is Nicholas of Damascus. ${ }^{78}$ He belongs in linguistic and literary terms to the Greek Hellenistic culture, and the circumstances of his life ${ }^{79}$ and the subjects of his historiographical works belong firmly to the beginnings of the Roman Imperial period. ${ }^{80}$

\subsection{Historiographical Authors in the Early Imperial Period (first/second century of the Common Era)}

Tables (1)-(3) list historiographical authors who worked in the period relevant to the New Testament age, i.e. the early Imperial period, in the Greek Hellenistic, Roman, and early Jewish linguistic and cultural spheres. Those authors are listed who present historical themes in prose form. ${ }^{81}$

76 "The normative view of the exemplary knowledge of tradition, indeed of a value untouched by change (auctoritas), gave the historians (Livy, Sallust, Tacitus) the freedom to combine and make a stylistic synthesis of various forms of presentation, in order to write persuasively: forms drawn from oratory, literature, and dialectics such as narrative, description, argumentation, dramatization, fictitious speech, the narrative of events, commentaries, aphorisms": Harth, "Geschichtsschreibung," 839.

77 With regard to Tacitus, cf. the presentation by D. Flach, Tacitus in der Tradition der antiken Geschichtsschreibung, Hyp. 39 (Göttingen: Vandenhoeck und Ruprecht, 1973), 14-16.

${ }^{78}$ In general, cf. R. Laqueur, "Nikolaos," RE 17 (1937): 362-424.

${ }^{79} \mathrm{He}$ is one of the Greek-speaking historians who "themselves worked in Rome" in increasing numbers from the late Republican period onward, "or at any rate were closely connected to the great men of Rome": A. Dihle, Die griechische und lateinische Literatur der Kaiserzeit: Von Augustus bis Justinian (München: C. H. Beck, 1989), 153.

${ }^{80}$ On this, cf. also M. Kober, Die politischen Anfänge Octavians in der Darstellung des Velleius und dessen Verhältnis zur historiographischen Tradition: Ein philologischer Quellenvergleich. Nikolaus von Damaskus, Appianos von Alexandria, Velleius Paterculus, Epistemata 286 (Würzburg: Königshausen \& Neumann, 2000); M. Toher, The "Bios Kaisaros" of Nicolaus of Damascus: An Historiographical Analysis: (unpublished Ph.D. dissertation. Brown University, 1985).

${ }^{81}$ For secondary literature, cf. n. 1 above. 


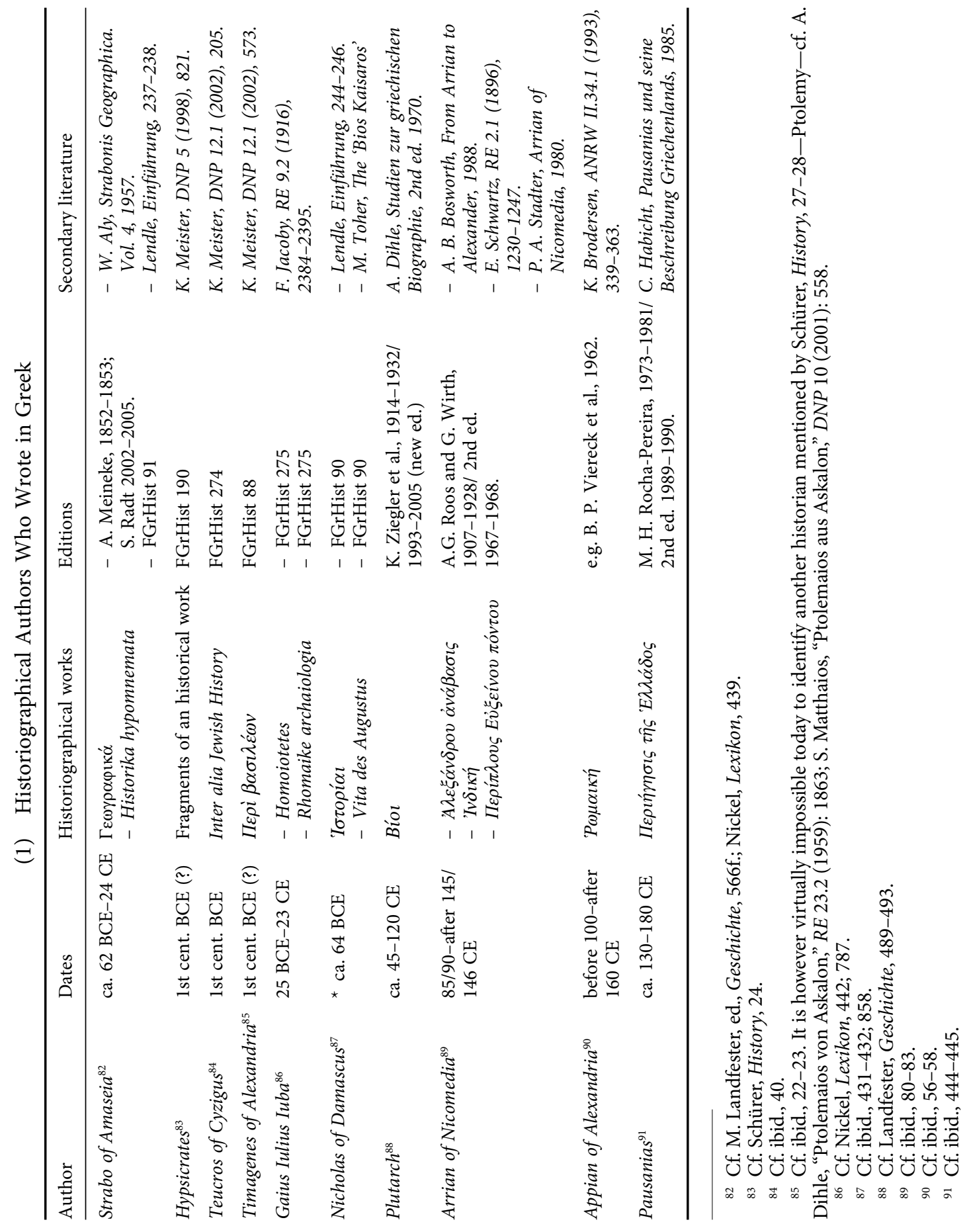


HISTORIOGRAPHICAL LITERATURE IN THE NEW TESTAMENT 1805

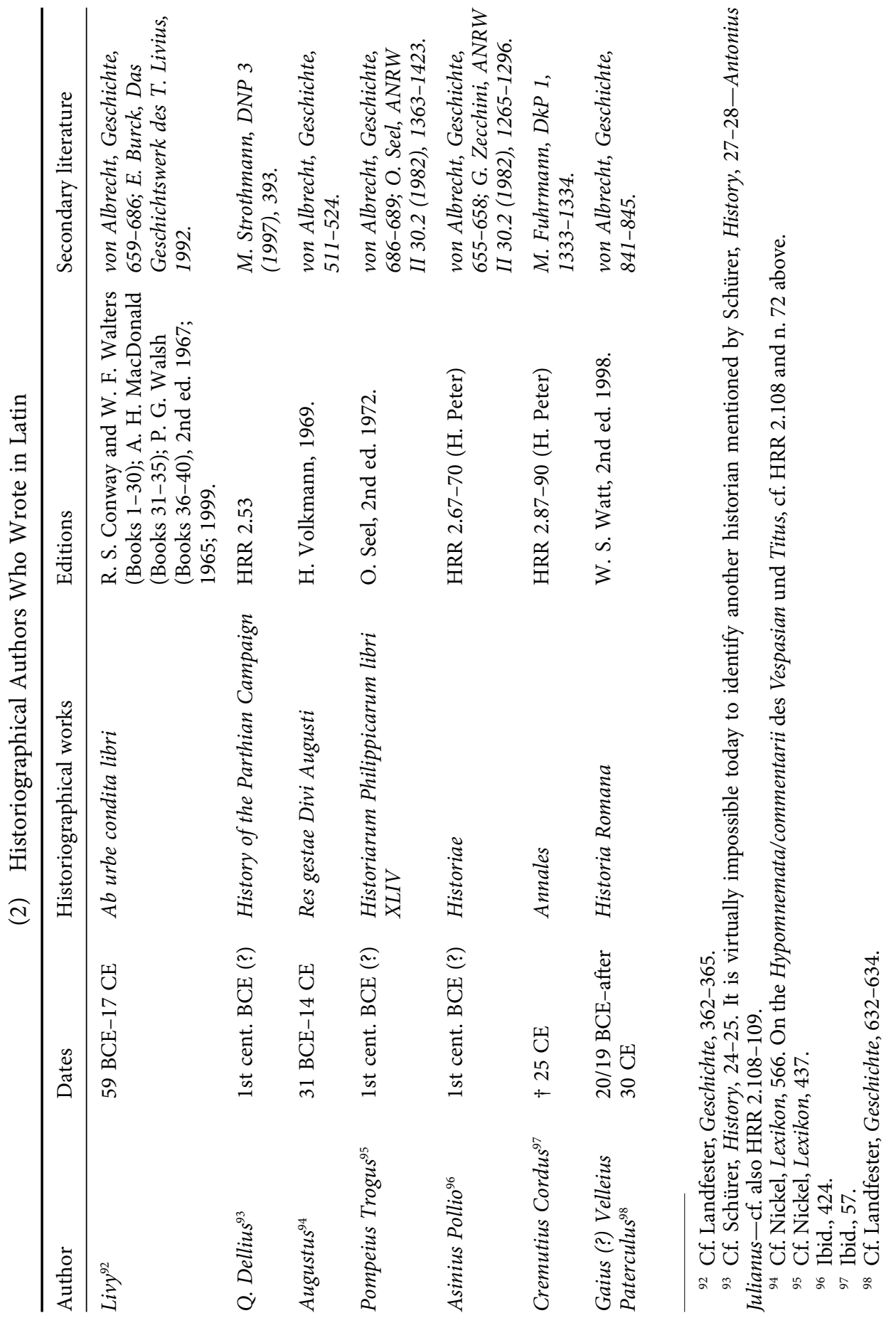




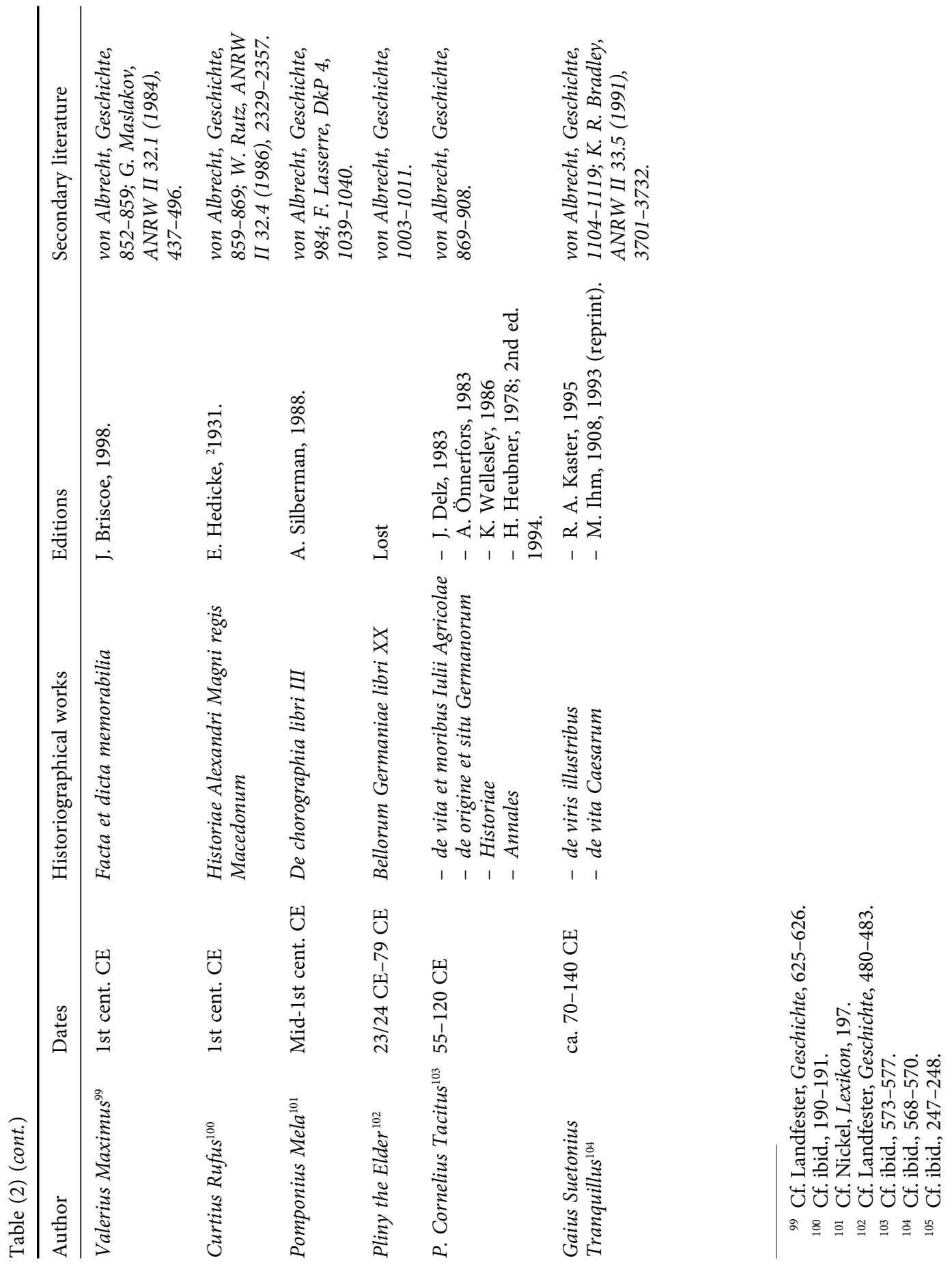


HISTORIOGRAPHICAL LITERATURE IN THE NEW TESTAMENT 1807

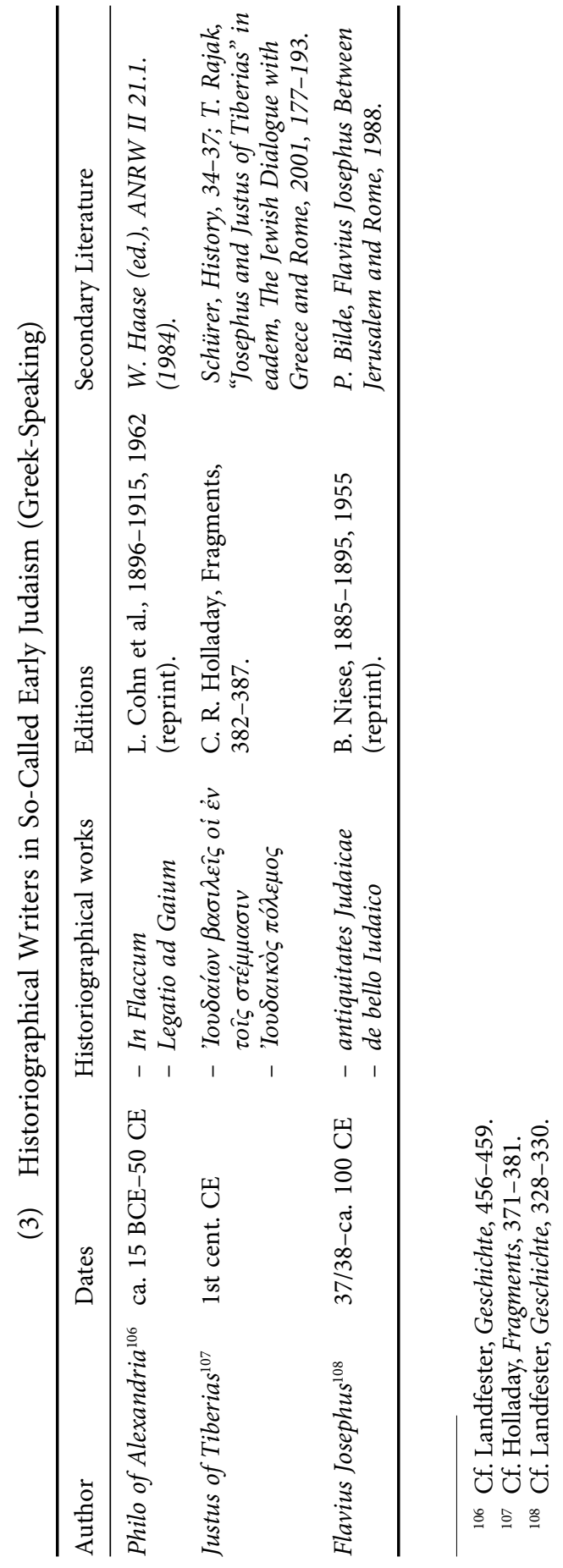


This means that this overview has the following boundaries. Authors

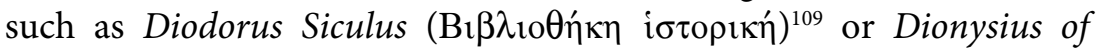

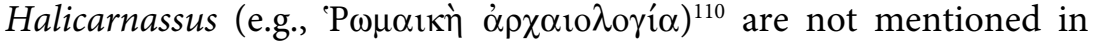
the following tables, because the dates of their lives do not belong clearly to the transition to the first century of the Common Era (Diodorus: first century BCE; Dionyius: ca. 60 BCE-after 7 CE). Authors such as Ovid (43 BCE-17 CE) $)^{111}$ or the Alexandrian Dionysius Periegetes (first half of the second century $\mathrm{CE}$ ) ${ }^{112}$ are not included, because the works they wrote on historical themes are not composed in prose: the Fasti of Ovid is in elegiac distiches, and the Periegesis of Dionysius is in hexameters.

\section{Early Christian Literature in the Framework of Ancient Historiography}

\subsection{Basic Questions}

The Greek Hellenistic, Jewish Hellenistic, and Roman historiographies of the Hellenistic Roman period display distinctive characteristics not only in their language, but also in their ideas and choice of subjects. In its very origins, historiography is closely linked to culture and context. This also applies to the social status of the historian. ${ }^{113}$ In the Hellenistic-Roman period, however, processes of assimilation begin. ${ }^{114}$

109 Cf. Landfester, Geschichte, 201; Lendle, Einführung, 242-244.

${ }^{110}$ Cf. Landfester, Geschichte, 215-216; Lendle, Einführung, 239-241.

111 Cf. Landfester, Geschichte, 424-425; Gall, Literatur, 151-153.

112 Cf. Landfester, Geschichte, 213.

${ }^{113}$ For an exemplary study of the question of the social status of Josephus, cf. G. W. Bowersock, "Foreign Elites at Rome," in Flavius Josephus and Flavian Rome, ed. J. Edmondson et al. (Oxford: Oxford University Press, 2005), 53-62. A wide field for sociological research opens up here, as H. Schneider has shown: "At present, the modern social history of classical antiquity displays a rich variety of themes...the level of education, e.g. the ability to write and read, and status symbols ... are the object of a research which moves between the disciplines and is able to draw on the questions and methodologies of the modern social sciences": "Sozial- und Wirtschaftsgeschichte," DNP 15.3 (2003): 83-92, at 90.

${ }_{114}$ For the early Jewish area, following on the studies by V. Tcherikover (e.g. Hellenistic Civilization and the Jews [Philadelphia: Jewish Publication Society of America, 1959]), cf. the standard works, e.g. M. Hengel, "The Interpenetration of Judaism and Hellenism in the pre-Maccabean Period," in The Cambridge History of Judaism 2, ed. W. D. Davies and L. Finkelstein (Cambridge: Cambridge University Press, 1989), 167-228; E. S. Gruen, Diaspora: Jews amidst Greeks and Romans (Cambridge: Harvard University Press, 2002). 
The three cultural spheres-Greek, Roman, and Jewish-which were initially rather independent of each other came into contact and mingled. This cultural exchange and transfer took place in specific political constellations, first in the Hellenistic Macedonian hegemony, then in the period of the successor kings, and then in the imperial expansion of the Romans. This can be illustrated by some well-known examples:

- Diaspora Judaism speaks and writes Greek;

- the development of Roman literature finds its orientation in earlier Greek Hellenistic works;

- the Hellenistic historian Polybius discovers the significance of Roman history for the eastern Mediterranean region;

- the Greek Hellenistic compiler Alexander Polyhistor devotes his energies to the collection of Jewish historiographical works.

These processes of assimilation reach their peak thanks to the geographical expansion of the Roman empire under Augustus and to the consolidation of the political, military, and institutional structures in the early Imperial period. In this period, the shared elements of culture become important, and one can say that a new type of culture emerges, as can be seen (to a limited extent) in the Jewish Hellenistic literature of the first century CE. Here, we think first of all of Josephus, ${ }^{115}$ but also of some writings by Philo of Alexandria which have at least a partly historiographical character (e.g. the Legatio ad Gaium and In Flaccum). ${ }^{116}$ It is interesting to see that the Jewish Hellenistic literature shares the common Hellenistic syntheses especially in the field of historiography.

115 For a structural comparison between historiographical elements in Josephus and in the Gospel of Mark, cf. Becker, Markus-Evangelium, 301-303. Only a few structural comparisons with regard to the literary-historical aspects in the historiographical writings of Josephus will be found in C. Böttrich and J. Herzer, eds., Josephus und das Neue Testament: Wechselseitige Wahrnehmungen, WUNT 209 (Tübingen: Mohr Siebeck, 2007); cf. the essay by M. Vogel, "Geschichtsschreibung nach den Regeln von Lob und Tadel. Sterbeszenen bei Josephus und im Neuen Testament," in Josephus, ed. Böttrich and Herzer, 535-546. On the essence and function of historiography in general, cf. D. E. Aune, "Historiography," in idem, The Westminster Dictionary of New Testament \& Early Christian Literature \& Rhetoric (Louisville: Westminster John Knox Press, 2003), 215-218.

116 Cf. table (3). On this, cf. also P. W. van der Horst, "Philo's In Flaccum and the Book of Acts," in idem, Jews and Christians in Their Graeco-Roman Context: Selected Essays on Early Judaism, Samaritanism, Hellenism, and Christianity, WUNT 196, (Tübingen: Mohr Siebeck, 2006), 98-107; and in general, cf. also Schürer, History, $859-864$. 
The genesis of the earliest Christian texts coincides with this situation, which is determined politically by the conditions of the early Imperial period and in terms of cultural and literary history by the assimilation processes of the Hellenistic-Roman period. In what follows, I concentrate on the texts in the New Testament, and then refer only briefly (see section e) to extra-canonical texts (the so-called Apostolic Fathers, apocrypha, etc.) which are related to historiography and were written at roughly the same time as the New Testament texts.

\subsection{The Gospels as Historiographical Literature-Example: The Gospel of Mark}

From Gotthold E. Lessing onwards, the gospel literature, especially the synoptic gospels, have been read as history-oriented accounts of the life and work of Jesus of Nazareth. ${ }^{117}$ Modern gospel research ${ }^{118}$ also sees close links between the gospels and biographical literature: the gospels take up elements which are known from the official prophetic biography of the Old Testament (cf. Helmut Koester), ${ }^{119}$ and their genre is comparable to that of the pagan biographies of classical antiquity (cf. Detlev Dormeyer). ${ }^{120}$ The identification of a structural closeness between the gospels and biographical literature means that they belong to the genre of historiography in the broader sense (cf. also Richard A. Burridge) ${ }^{121}$ Adela Yarbro Collins agrees in this basic classification of the gospels as historiographical literature, and has recently

117 Cf. G. E. Lessing, "Theses aus der Kirchengeschichte," in idem, Werke und Briefe in zwölf Bänden, 8: Werke 1774-1778, ed. A. Schilson (Frankfurt: Deutscher Klassiker Verlag, 1989), 619-627; idem, Neue Hypothese über die Evangelisten als bloß menschliche Geschichtsschreiber betrachtet, Wolfenbüttel 1778, in Werke und Briefe, 8:629654.

${ }^{118}$ For an overview of research, cf. D. Dormeyer, Das Markus-Evangelium (Darmstadt: Wissenschaftliche Buchgesellschaft, 2005), esp. 112-137; Becker, Markus-Evangelium, 37-29.

119 Cf. H. Koester, "Überlieferung und Geschichte der frühchristlichen Evangelienliteratur," ANRW II 52.2 (1984): 1463-1542; idem, "Evangelium II. Gattung," RGG 4th ed., 2 (1999): 1735-1741.

${ }^{120}$ Cf. D. Dormeyer and H. Frankemölle, "Evangelium als literarische Gattung und als theologischer Begriff: Tendenzen und Aufgaben der Evangelienforschung im 20. Jahrhundert, mit einer Untersuchung des Markusevangeliums in seinem Verhältnis zur antiken Biographie," ANRW II 25.2 (1984): 1543-1704; Dormeyer, Markusevangelium, 1666-1668.

${ }^{121}$ Cf. e.g. H. Cancik, "Die Gattung Evangelium: Markus im Rahmen der antiken Historiographie," in idem, Markus-Philologie: Historische, literargeschichtliche und stilistische Untersuchungen zum zweiten Evangelium, WUNT 33 (Tübingen: Mohr [Paul Siebeck], 1984), 85-113; R. A. Burridge, What are the Gospels? A Comparison with 
described the Gospel of Mark more precisely as an historical monograph with eschatological tendencies. ${ }^{122}$ The literary-historical perspective which reads the gospel writings in the context of ancient historiography concentrates especially on the Gospel of Luke (see below); recently, the Gospel of John too has been read in this light (Richard Bauckham). ${ }^{123}$

The discussion of the historiographical character of the Gospel of Mark can be illustrated by a recent approach (2006): I agree that Mark should be classified under historiographical literature in the broader sense. ${ }^{124}$ Unlike the approaches mentioned above, my approach demarcates the Gospel of Mark vis-à-vis biographical literature by highlighting its (sub-)historiographical character, which I describe as follows. First, on the basis of Mark 1:1, the theme of the Gospel of Mark is seen as an event-historical monographic narrative of the beginning of the gospel. ${ }^{125}$ Secondly, the focus on the figure of Jesus is not primarily evaluated against the background of ancient biographies; it is seen as a person-centered presentational element which is known from Jewish Hellenistic historiography (Artapanus). ${ }^{126}$ Thirdly, the way in which the Gospel of Mark employs its sources and the interpretation of the historical narrative makes it comparable to works of ancient historiography (e.g. Polybius and Sallust). ${ }^{127}$ In particular, the integration of the passion narrative (Mark 14-16), which to begin with has clear biographical traits when compared to the ancient exitus literature, ${ }^{128}$ into the total structure of the gospel presentation should be understood as a tendency to emphasize historiographical structures and to reduce

Graeco-Roman Biography, SNTSMS 70 (Cambridge: Cambridge University Press, 1992).

${ }_{122}$ Cf. A. Yarbro Collins, Mark: A Commentary, Hermeneia (Minneapolis; Fortress Press, 2007), 42: "Mark as an Eschatological Historical Monograph"; eadem, "Markusevangelium," RGG 4th ed., 5 (2002): 842-846.

${ }^{123}$ Cf. R. Bauckham, "Historiographical Characteristics of the Gospel of John," NTS 53 (2007): 17-36.

${ }^{124}$ Cf. Becker, Markus-Evangelium; eadem, "The Gospel of Mark in the Context of Ancient Historiography," in The Function of Ancient Historiography in Biblical and Cognate Studies, ed. P. G. Kirkpatrick and T. Goltz (New York: T \& T Clark, 2008), 124-134.

${ }_{125}$ Cf. Becker, Markus-Evangelium, 102-104.

126 Cf. ibid., 178-180.

${ }_{127}$ Cf. ibid., 149-151; 213-215.

${ }^{128}$ Cf. e.g. U. Eigler, "Exitus illustrium virorum," DNP 4 (1998): 344-345; F. A. Marx, "Tacitus und die Literatur der exitus illustrium virorum," Phil 92 (1937): 83103; A. Ronconi, "Exitus illustrium virorum," RAC 6 (1966): 1258-1268. 
biographical narrative traits (cf. also Tacitus, Ann. 15.60-62). ${ }^{129}$ This means that the Gospel of Mark is a sub-historiographical writing and forms a genre sui generis in the field of Hellenistic historiography in the broader sense.

\subsection{The Lukan Writings as Historiographical Literature}

The so-called Lukan double work has a special position in historiographical research. Here, Martin Dibelius ${ }^{130}$ and Ernst Haenchen, ${ }^{131}$ and most recently the studies by Eckhard Plümacher, ${ }^{132}$ have interpreted the author Luke, especially in the Acts of the Apostles, as an historian. ${ }^{133}$ In this context, the comparison with Hellenistic-Roman historiography has led scholars to make a detailed identification of historiographical narrative and stylistic elements (e.g. the motifs of miracles ${ }^{134}$ and the topos of the praefationes). ${ }^{135}$ Besides this, the following formal elements are "decisive" for the classification of the Acts

129 Cf. Becker, Markus-Evangelium, 362-364.

${ }^{130}$ Cf. e.g. M. Dibelius, "Die Reden der Apostelgeschichte und die antike Geschichtsschreibung" (1949), in idem, Aufsätze zur Apostelgeschichte, ed. H. Greeven, 5th ed. FRLANT 42 (Göttingen: Vandenhoeck \& Ruprecht, 1968), 120-162.

${ }_{131}$ Cf. E. Haenchen, Die Apostelgeschichte, 6th ed. KEK 3 (Göttingen: Vandenhoeck \& Ruprecht, 1968), 81-83.

132 Cf. E. Plümacher, "Lukas als griechischer Historiker," RE.S 14 (1974): 235-264; idem, "Geschichtsschreibung IV. Biblisch 2. Neues Testament," RGG 3rd ed. (2000): 808. Cf. also various essays in idem, Geschichte und Geschichten: Aufsätze zur Apostelgeschichte und zu den Johannesakten, ed. J. Schröter and R. Brucker, WUNT 170 (Tübingen: Mohr Siebeck, 2004). Cf. most recently also idem, "Hellenistische Geschichtsschreibung im Neuen Testament. Die Apostelgeschichte," in Geschichte und Vergangenheit. Rekonstruktion, Deutung, Fiktion, ed. U. H. J. Körtner (NeukirchenVluyn: Neukirchener Verlag, 2007), 115-127.

${ }_{133}$ Cf. also D. E. Aune, The New Testament in Its Literary Environment (Cambridge: Westminster Press, 1987), 77-79; D. Dormeyer, Das Neue Testament im Rahmen der antiken Literaturgeschichte. Eine Einführung (Darmstadt: Wissenschaftliche Buchgesellschaft, 1993), 228-230; J. Schröter, "Lukas als Historiograph. Das lukanische Doppelwerk und die Entdeckung der christlichen Heilsgeschichte," in Die antike Historiographie und die Anfänge der frühchristlichen Geschichtsschreibung, ed. Becker, 237-262.

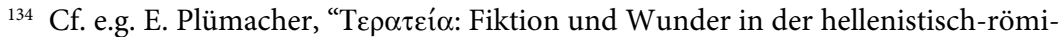
schen Geschichtsschreibung und in der Apostelgeschichte," in idem, Geschichte und Geschichten, ed. Schröter and Brucker, 33-83.

${ }_{135}$ Cf. L. C. A. Alexander, "The Preface to Acts and the Historians," in History, Literature and Society in the Book of Acts, ed. B. Witherington (Cambridge: Cambridge University Press, 1996), 73-103; D. E. Aune, "Preface," in idem, The Westminster Dictionary of New Testament \& Early Christian Literature \& Rhetoric, 367-372, esp. at 369-371. 
of the Apostles under historiographical literature: "a foreword, synchronization, speeches, and letters." 136 In the case of the Gospel of Luke, the closeness of the author and his work to Hellenistic-Roman historiography is much discussed, ${ }^{137}$ especially by Anglo-American exegetes. ${ }^{138}$ In this context, the praefatio or prooemium at Luke 1:1-4 is significant, since it recalls the topos of ancient historiographers (cf. also Josephus, War 1.1-30). ${ }^{139} \mathrm{We}$ also find other individual narrative and compositional historiographical elements in the Gospel of Luke, e.g. the synchronisms in Luke 2:1 and 3:1, the speeches (Luke 6:20-22;

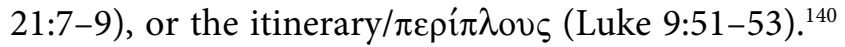

\subsection{Texts and Forms in the New Testament Literature Related to the Historiographical Genre}

We now present texts and forms which display two characteristics that were described above as typical of historiography in the broader sense: these are texts written in prose, which are concerned with the interpretation of history. Unlike the gospel literature and the Acts of the Apostles, however, these are mostly shorter individual texts which are a part of a larger writing that cannot be classified under the macro-genre of historiography, because of its own specific characteristics. Such texts belong rather to the genre of letter or apocalypse.

136 J. Jervell, Die Apostelgeschichte, KEK 3 (Göttingen: Vandenhoeck \& Ruprecht, 1998), 77. Jervell classifies Acts more precisely as "tragic historiography" 78).

${ }^{137}$ However, this question is not raised in the two most recent German commentaries on the Gospel of Luke, when they discuss the genre of the Gospel: cf. H. Klein, Das Lukasevangelium, KEK I.3 (Göttingen: Vandenhoeck \& Ruprecht, 2006); M. Wolter, Das Lukasevangelium, HNT 5 (Tübingen: Mohr Siebeck, 2008).

138 Cf. e.g. J. Fitzmyer, The Gospel According to Luke I-IX, AB 28 (New York: Doubleday, 1981), 171-173; F. Bovon, Das Evangelium nach Lukas. 1. Teilband (Lk 1,19,50, EKK III.1 (Neukirchen-Vluyn: Neukirchener Verlag, 1989), 18-19; J. B. Green, The Gospel of Luke, NICNT (Grand Rapids: Eerdmans, 1997), 1-6. Cf. also Aune, New Testament, 80-82.

${ }_{139}$ Cf. Fitzmyer, Gospel, 287-289; Green, Gospel, 33-35; and most recently Wolter, Lukasevangelium, 57-61. On research into the Lukan prologue, cf. in general L. Alexander, The Preface to Luke's Gospel: Literary Convention and Social Context in Luke 1.1-4 and Acts 1.1 (Cambridge: Cambridge University Press, 1993).

${ }_{140}$ Cf. most recently Wolter, Lukasevangelium, 364-366. 


\section{Autobiographical passages in Paul}

To the extent that autobiographical narrationes have an historiographical tendency (cf. my remarks above on the hupomnematal commentarii), some passages in the Pauline letters come close in their intention to historiography. ${ }^{141}$ Here, Galatians $1-2$ and 2 Corinthians 11-12 are particularly relevant. The themes which Paul treats autobiographically vary between an account of his previous missionary activity (1 Thess $1 ; 3 ; 1$ Cor 2-3) and a reflection on his own person in the light of his vocation (e.g., 1 Cor 15:3-5) and his apostolate or apostolic mode of life (e.g. 1 Cor 9). ${ }^{142}$

\section{Prophecy, apocalyptic, and the interpretation of history}

Prophetic and apocalyptic texts also come under the heading of historiographical literature, where they formulate a look back on history and/or eschatological scenarios which are the outcome of the perception and interpretation of historical events and experiences. This has prompted Georges Minois to see an historical and historiographical dimension in oracles and prophecies. ${ }^{143}$ In the New Testament literature, ${ }^{144}$ the most prominent apocalyptic texts are Mark 13 parr. and the Apocalypse of John. ${ }^{145}$ These have the function of interpreting and coping with history. In the literature of the so-called Apostolic Fathers, the concluding chapter of the Didache (16) can be called an apocalyptic text. ${ }^{146}$

${ }^{141}$ On this, cf. E.-M. Becker, "Autobiographisches bei Paulus: Aspekte und Aufgaben," in Biographie und Persönlichkeit des Paulus, ed. E.-M. Becker and P. Pilhofer, WUNT 187 (Tübingen: Mohr Siebeck, 2005/2009), 67-87, esp. 73-75; O. Wischmeyer, "Paulus als Ich-Erzähler: Ein Beitrag zu seiner Person, seiner Biographie und seiner Theologie," in Biographie, ed. Becker and Pilhofer, 88-105.

${ }_{142}$ On this overview, cf. Becker, "Autobiographisches", 82-83.

${ }^{143}$ Cf. G. Minois, Geschichte der Zukunft: Orakel, Prophezeiungen, Utopien, Prognosen (Düsseldorf and Zurich: Artemis and Winkler, 1998).

${ }_{144}$ On this, cf. P. Vielhauer and G. Strecker, "Einleitung," in Schneemelcher, Apokryphen 2, 491-515, esp. at 495-497.

${ }_{145}$ Cf. Vielhauer and G. Strecker, "Einleitung," 525-527. On the special question of the historical/temporal dimensions of the Apocalypse of John, cf. D. E. Aune, Revelation 1-5, WBC 52A (Dallas: Word Books, 1997), lxxxiv-lxxxv.

${ }^{146}$ Cf. Vielhauer and Strecker, "Einleitung," 535-537. 
3.5. Texts and Forms in the New Testament Apocrypha Related to the Historiographical Genre

In conclusion, I mention the texts and writings from the field of the so-called New Testament apocrypha which are related to the historiographical genre and may have been composed in the New Testament period as this was defined above, i.e. no later than the midsecond century. Once again, these are prose texts which are concerned with the interpretation of history. These texts must be distinguished from others such as the Coptic Gospel of Thomas ${ }^{147}$ and the Gospel of Philip, ${ }^{148}$ which belong to the literary genre of the collection of logia or florilegium, from the Shepherd of Hermas, which is a parenetic text, ${ }^{149}$ and from so-called revelation dialogues such as the Book of Thomas. ${ }^{150}$ The overview in Table (4) attempts to classify the relevant texts and writings under the three literary forms and genres (gospel, Acts-literature, related forms/apocalypses) which we already find in the New Testament literature. This also brings to light literaryhistorical continuities and developments between New Testament literature and Christian literature outside the New Testament, and shows their closeness to the historiographical macro-genre. ${ }^{151}$

${ }^{147}$ Cf. B. Blatz, "Das koptische Thomasevangelium," in Schneemelcher, Apokryphen 1, esp. 93-97.

${ }_{148}$ Cf. H.-M. Schenke, "Das Evangelium nach Philippus," in Schneemelcher, Apokryphen 1, esp. 148-154.

${ }_{149}$ Cf. Vielhauer and Strecker, "Einleitung", 537-547; Moreschini and Norelli, Literature, $160-165$.

${ }_{150}$ Cf. H.-M. Schenke, "Das Buch des Thomas," in Schneemelcher, Apokryphen 1, esp. 192-198.

${ }_{151}$ This article is dedicated to Wolfgang Wischmeyer, Vienna, on the occasion of his 65th birthday (5 October 2009). 


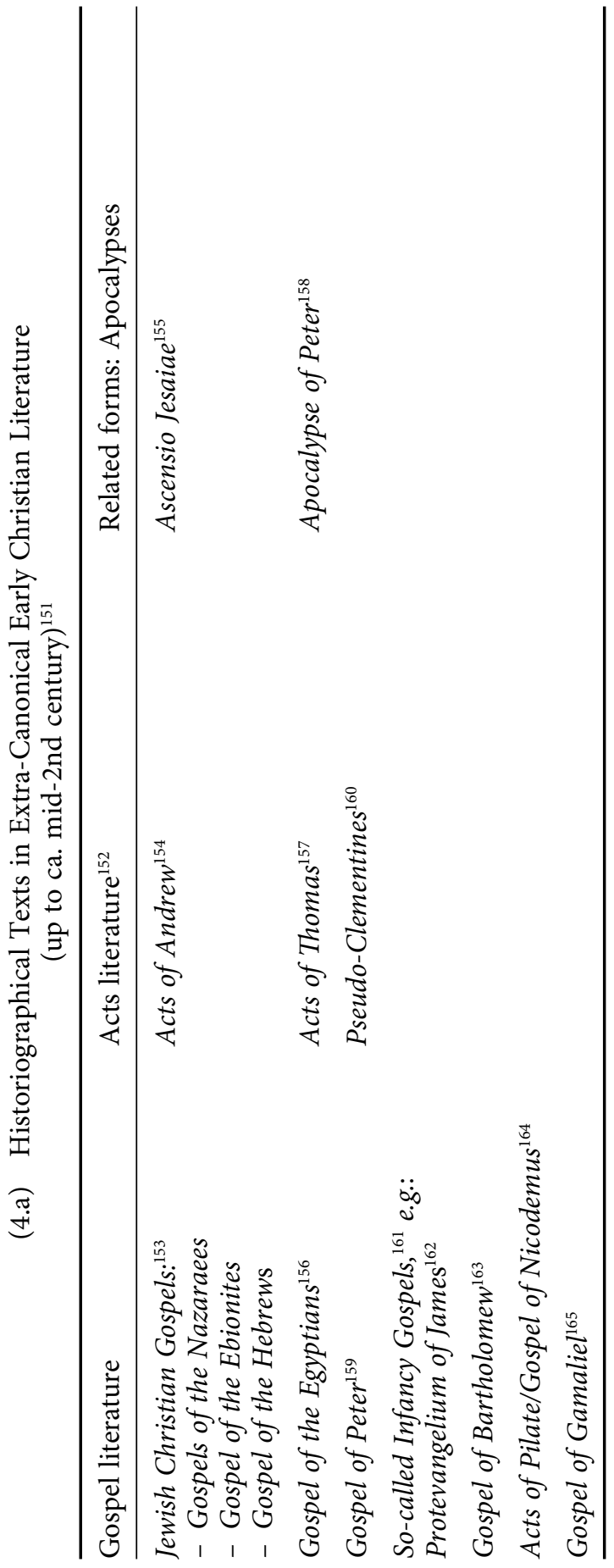

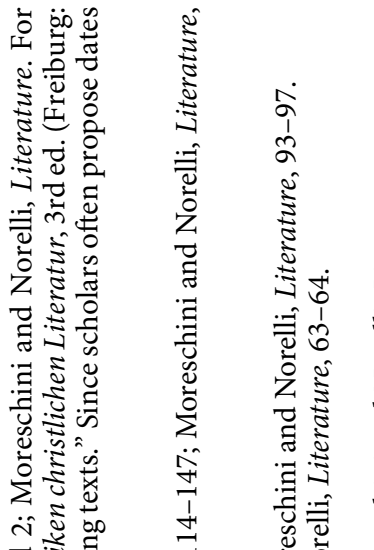

$\stackrel{8}{\circ}$

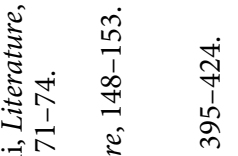

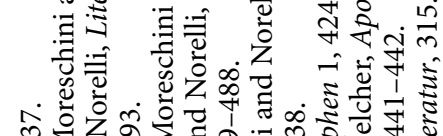

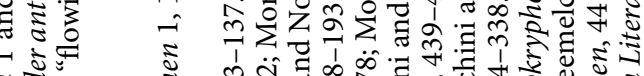

₹

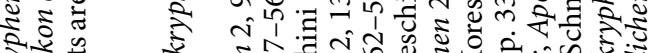

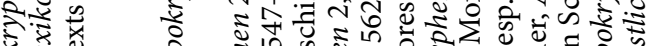

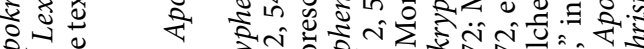

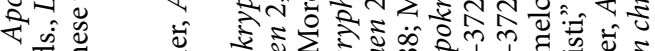

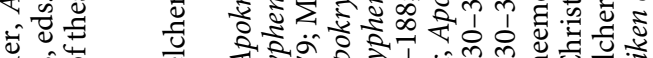
娄

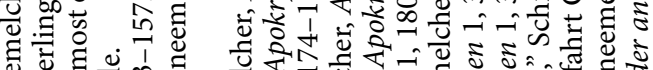

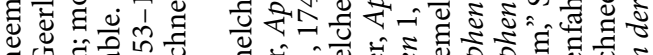

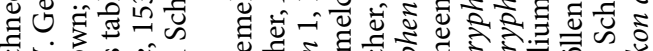

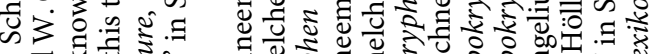
نं

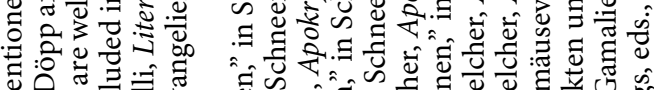

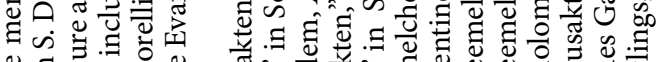

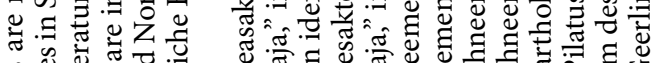

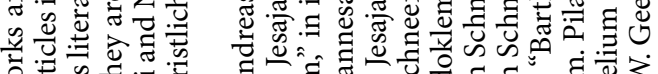

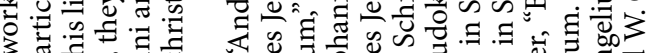

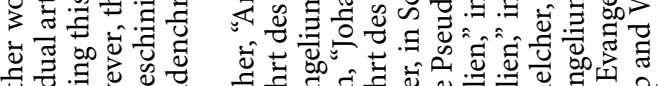

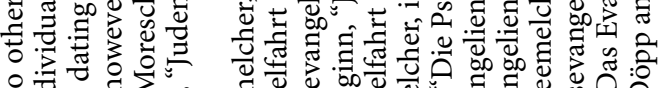
\&.尹 品.

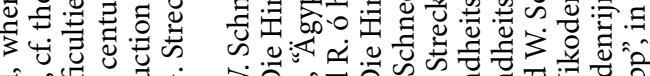

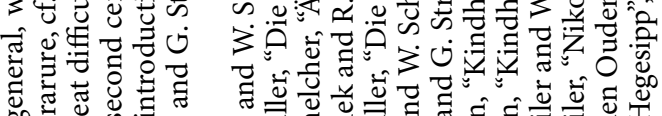

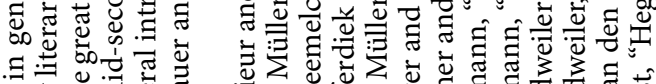

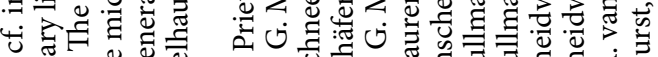

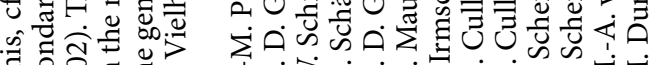

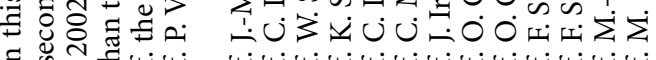
○ี

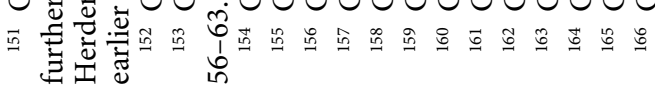


HISTORIOGRAPHICAL LITERATURE IN THE NEW TESTAMENT 1817

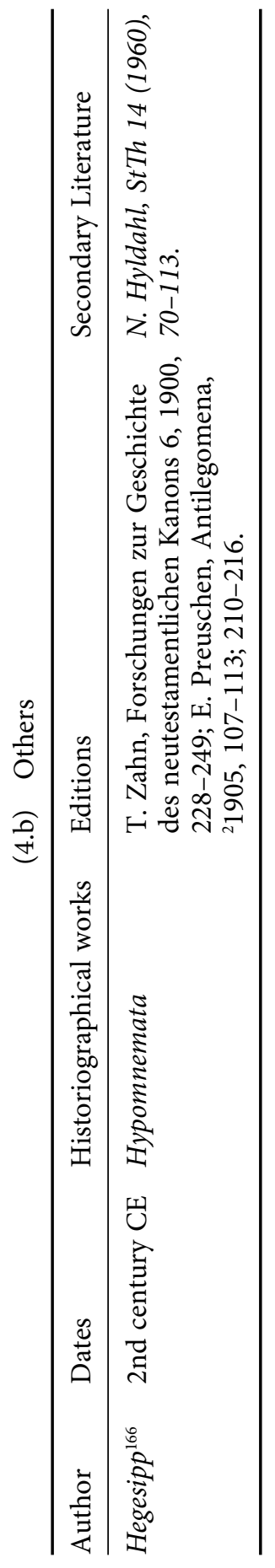


